\title{
Factors Affecting Self-Efficacy on Tuberculosis Patients
}

\author{
Abdul Muhith ${ }^{1}$, Mukhammad H. Saputra*2, Sandu Siyoto ${ }^{3}$, Eny Dwi ${ }^{4}$ \\ ${ }^{1,2,4}$ STIKes Majapahit Mojokerto, Indonesia \\ Jalan Raya Gayaman Km. 02 Mojoanyar Kota Mojokerto 61364. \\ ${ }^{3}$ STIKes Surya Mitra Husada, Kediri, Indonesia \\ Jalan Manila, Nomor 37, Pesantren, Kota Kediri, Jawa Timur 64133 \\ *Corresponding author: mhimawansaputra@gmail.com
}

\begin{abstract}
Background:Tuberculosis was a contagious infectious disease caused by Mycobacterium tuberculosis. Patients who are diagnosed Pulmonary Tuberculosis will arise fear in him. It was important for tuberculosis patients to have the confidence to heal or self-efficacy. Objectives:The purpose of this study was to analyze the factors that affect self-efficacy in Tuberculosis patients at Tikung Health Center, Lamongan District.Method: Research design in this research use crosssectional design with research character is explanatory research. Results:The most patients had positive self-efficacy. Based on the statistical test shows that the mastery experiences, vicarious experience, social persuasion, and physiological conditions affect the efficacy of tuberculosis patients at Tikung Lamongan Public Health Center.Conclusion:The role of nurses was very important in optimizing the factors that affect the beliefs of people suffering from tuberculosis at Tikung Health Center, Lamongan regency, for example by providing consultation related to the illness, so as to increase his conviction to be able to recover and live normally in the community.
\end{abstract}

Keywords: Self-efficacy, patient, tuberculosis, factors

\section{INTRODUCTION}

Tuberculosis is a contagious infectious disease caused by Mycobacterium tuberculosis. Mycobacterium tuberculosis is transmitted through droplets in the air, so tuberculosis patients are the source of the cause of transmission in surrounding population. Until now lung tuberculosis is still a major health problem, both in the world and in Indonesia. The phenomenon in society today, there are still family members who are afraid to be close to someone suspected tuberculosis, so that appear excessively cautious attitude, such as distancing themselves from the patient, reluctant to talk, if close to the patient will immediately close their nose. It will be very offensive to the patient. Patients will be depressed and feel ostracized, so it can have an impact on the psychological condition and eventually will happen success, this psychic complaint will beat the quality of life (Lisdawati, et al, 2015).

The prevalence of pulmonary tuberculosis at Tikung Health Center of Lamongan obtained from medical record in 2015 reached 84 patients while in 2014 reached 98 patients.One of the factors affecting patient self-care management is self-efficacy. Selfefficacy is an individual's belief in his ability to organize and perform a specific task for the achievement of goals (Bandura, 1982). 


\section{METHOD}

Research design in this research use cross-sectional design with research character is explanatory research, based on respondent's perception. The population in this study were all Tuberculosis patients recorded at Tikung Health Center of Lamongan District from January to December 2016, a total of 60 people.The sampling technique used is simple random sampling, with a total sample of 52. The research was conducted in working area of a Tikung public health center in Lamongan. The study was conducted from May to June 2017. Bivariate analysis using Chi-square test with $95 \%$ significance level or $\mathrm{p}=0.05$

\section{RESULTS AND DISCUSSION}

Results showed that most respondents have positive mastery experience and have positive self-efficacy, is 29 respondents $(55,8 \%)$. Chi-square test results showed that the respondent mastery experience was positively and significantly correlated with the self efficacy of tuberculosis patients (p-Value: $0,000, \alpha$ value: 0.05 ).In line with the research conducted by Wieland, et al(2013) shows the results among the four factors that play a role in the development of self-efficacy, mastery experience factor is the most important factor in improving self-efficacy (Wieland, et al, 2013). Self-efficacy is formed through the social learning process that can occur in the social environment Self-efficacy is formed as a process of adaptation and learning that exist in the theme. Success builds confidence. Difficulties or failures are part of the experience of mastery that will be the basis of the ability to control every situation (Bandura, 1982; Swaminathan, et al, 2011). Self-efficacy is closely related to successful experience, people who successfully solve a self-efficacy problem will increase, otherwise people who fail to solve a self-efficacy problem will go down (speak at the time of self-efficacy has not formed steadily in a person).

Table 1 Cross-tabulation between the Mastery Experience and Self-Efficacy

\begin{tabular}{|c|c|c|c|c|c|c|c|}
\hline \multirow{3}{*}{ No } & \multirow{3}{*}{ Mastery Experience } & \multicolumn{4}{|c|}{ Self-Efficacy } & \multirow{2}{*}{\multicolumn{2}{|c|}{ Total }} \\
\hline & & \multicolumn{2}{|c|}{ Positive } & \multicolumn{2}{|c|}{ Negative } & & \\
\hline & & $\mathrm{f}$ & $\%$ & $\mathrm{f}$ & $\%$ & $\mathrm{f}$ & $\%$ \\
\hline 1 & Positive & 29 & 55,8 & 2 & 3.8 & 31 & 59,6 \\
\hline 2 & Negative & 3 & 5,8 & 18 & 34,6 & 21 & 40,4 \\
\hline & Total & 32 & 61,5 & 20 & 38,5 & 52 & 100 \\
\hline
\end{tabular}

Based on the results of research in the table above shows that most respondents have positive vicarious experience and have positive self-efficacy is 30 respondents $(57.7 \%)$. Chi-square test results showed that the vicarious experience was positively and significantly correlated with the self efficacy of tuberculosis patients (p-Value: $0,000, \alpha$ : 0.05).Experience in observing others who have succeeded in doing a task will increase individual confidence that they can do the task and have the same abilities as their rolemodels. The magnitude of the influence of role-model on one's self-efficacy is highly dependent on how one feels similar to the model it imitates and then compares with itself (in how much similarities exist). The individual does not depend on his own experience of failure and success as the source of his self-efficacy. Self-efficacy is also influenced by the experience of other individuals(Bandura, 1982). 
Table 2 Cross-tabulation between the Vicarious Experience and Self-Efficacy

\begin{tabular}{|c|c|c|c|c|c|c|c|}
\hline \multirow{3}{*}{ No } & \multirow{3}{*}{ Vicarious Experience } & \multicolumn{4}{|c|}{ Self-Efficacy } & \multirow{2}{*}{\multicolumn{2}{|c|}{ Total }} \\
\hline & & \multicolumn{2}{|c|}{ Positive } & \multicolumn{2}{|c|}{ Negative } & & \\
\hline & & $\mathrm{F}$ & $\%$ & $\mathrm{f}$ & $\%$ & $\mathrm{~F}$ & $\%$ \\
\hline 1 & Positive & 30 & 57,7 & 3 & 5.8 & 33 & 63,5 \\
\hline 2 & Negative & 2 & 3,8 & 17 & 32,7 & 19 & 36,5 \\
\hline & Total & & 32 & 61.5 & 20 & 38,5 & 52 \\
\hline \multicolumn{8}{|c|}{$\mathrm{p}$ Value: $0,000 . \alpha: 0,05$} \\
\hline
\end{tabular}

Individual observation of the success of other individuals in a particular field will enhance the individual's self-efficacy in the same field. Individuals persuade themselves by saying that if other individuals can do so successfully, then the individual also has the ability to do well (Swaminathan, et al, 2011). Individual observation of the failures experienced by other individuals despite many attempts to decrease individual judgment on one's own ability and reduce individual effort to achieve success. There are two circumstances that allow the individual self-efficacy to be easily influenced by the experience of another individual, namely the lack of individual understanding of the ability of others and the lack of individual understanding of his or her own ability (Muhith, Saputra, \& Siyoto, 2017).

Based on the results of research in the table above shows that most respondents have positive social experience and have positive self-efficacy is 29 respondents (55.8\%). Chi-square test results showed that the social persuasions were positively and significantly correlated with the self efficacy of tuberculosis patients (p-Value: 0,000, $\alpha$ : 0.05).Basically verbal persuasion is a communication ability that can persuade or direct others. In persuasion communication, there is a component or element so it can be called as communication persuasion. These components include; Have a good persuasion purpose, an order wrapped with a solicitation or persuasion so as not to impose and based on the data or facts used to strengthen the argumentation (Swaminathan, et al, 2011; Cramm, et al, 2013). In verbal persuasion, individuals are directed by advice, advice, and guidance so as to enhance their beliefs about the abilities they possess that can help achieve the desired goals. Individuals who are verbally convinced will tend to work harder to achieve success (Bandura, 1982; Mason, et al, 2015).

Table 3 Cross-tabulation between the Social Persuasion and Self-Efficacy

\begin{tabular}{|c|c|c|c|c|c|c|c|}
\hline \multirow{3}{*}{ No } & \multirow{3}{*}{ Social Persuasions } & \multicolumn{4}{|c|}{ Self-Efficacy } & \multirow{2}{*}{\multicolumn{2}{|c|}{ Total }} \\
\hline & & \multicolumn{2}{|c|}{ Positive } & \multicolumn{2}{|c|}{ Negative } & & \\
\hline & & $\mathrm{f}$ & $\%$ & $\mathrm{f}$ & $\%$ & $\mathrm{~F}$ & $\%$ \\
\hline 1 & Positive & 30 & 57,7 & 3 & 5.8 & 33 & 63,5 \\
\hline \multirow[t]{2}{*}{2} & Negative & 2 & 3,8 & 17 & 32,7 & 19 & 36,5 \\
\hline & Total & 32 & 61,5 & 20 & 38,5 & 52 & 100 \\
\hline \multicolumn{8}{|c|}{ p-Value: $0,000 . \alpha: 0,05$} \\
\hline
\end{tabular}

Based on the results of research shows that most of 52 respondents who have positive physiological state also has positive self-efficacy that is 29 respondents $(55,8 \%)$. Chi-square test results showed that there is a relationship between the physiological state with the self efficacy of tuberculosis patient. Changes in body condition and mood can affect self-efficacy, people will quickly conclude tiredness, pain, and mood swings as a hint about self-efficacy. In line with the Dill study indicating the efficacy of self-stopping drinking decreases at a time when the mood is sad (Korpershoek,Van der Bijl \&Hafsteinsdóttir, 2011). The alcoholic who initially felt confident to stop drinking (the level of self-efficacy stopped drinking) at a time when his mood sad confidence to be able 
to stop drinking liquor decreased (the level of self-efficacy stopped drinking) (WellsPrakers, et al, 1998; Swaminathan, et al, 2011).

Table 4 Cross-tabulation between the Physiological State and Self-Efficacy

\begin{tabular}{|c|c|c|c|c|c|c|c|}
\hline \multirow{3}{*}{ No } & \multirow{3}{*}{ Physiological State } & \multicolumn{4}{|c|}{ Self-Efficacy } & \multirow{2}{*}{\multicolumn{2}{|c|}{ Total }} \\
\hline & & \multicolumn{2}{|c|}{ Positive } & \multicolumn{2}{|c|}{ Negative } & & \\
\hline & & $\mathrm{f}$ & $\%$ & $\mathrm{f}$ & $\%$ & $\mathrm{f}$ & $\%$ \\
\hline 1 & Positive & 29 & 55,8 & 2 & 3,8 & 31 & 59,6 \\
\hline \multirow[t]{3}{*}{2} & Negative & 3 & 5,8 & 18 & 34,6 & 21 & 40,4 \\
\hline & Total & 32 & 61,5 & 20 & 38,5 & 52 & 100 \\
\hline & \multicolumn{7}{|c|}{ p-Value: $0,000 . \alpha: 0,05$} \\
\hline
\end{tabular}

In terms of physiological and mood conditions, self-efficacy may increase if: the body condition increases, stress decreases, negative emotions decreases, there is a correction of misinterpretation of the state of the body. At sad times self-assessment is likely to be low (meaningless). Self-assessment will be positive (high self-efficacy level) at the time of a happy mood, self-assessment will be negative (low self-efficacy level) at a time of sad mood (Bandura, 1982; Mason, et al, 2015).

\section{CONCLUSION}

Based on the results of the study can be concluded that the mastery experience of respondents, vicarious experiences, social persuasion, and physiological state affect the efficacy of tuberculosis patients at Tikung Lamongan Public Health Center.

\section{ACKNOWLEDGEMENT}

The authors thank to LPPM STIKes Majapahit Mojokerto, Chief of YKWK Kabupaten Mojokerto, Chief of STIKes Majapahit Mojokerto for supporting this research.

\section{REFERENCES}

Bandura, A, (1982). Self-efficacy mechanism in human agency. American Psychologist, $37(2), 122$.

Cramm, JM, Strating, MMH, Roebroeck, ME, \& Nieboer, AP. (2013). The Importance of General Self-Efficacy for the Quality of Life of Adolescents with Chronic Conditions, Social Indicators Research, 113(1), 551-561.

Korpershoek, C, Van der Bijl, J \&Hafsteinsdóttir, TB. (2011). Self-efficacy and its influence on recovery of patients with stroke: a systematic review, Journal of Advanced Nursing, 67(2), 1876-1894.

Lisdawati, V., Puspandari, N., Rif'ati, L., Soekarno, T., Melatiwati, M., Syamsidar, K.,\& Parwati, I., (2015). Molecular epidemiology study of Mycobacterium tuberculosis and its susceptibility to anti-tuberculosis drugs in Indonesia. BMC Infectious Diseases, 15(1), 366.

Mason, P.H, Singh, P, Nhung, D.T. , Ho, J., Nguyen, T.A.1, Fox, G \& Marks, G.B. (2015). Coping Self-efficacy for Tuberculosis Treatment in Ca Mau, Vietnam, Againts Tuberculosis. 
Muhith, A., Saputra, H., \& Siyoto, S., (2017). The Correlation Between Healthy House Condition and Dyspnea Frequency of Pulmonary Tuberculosis Patients. Publikasi Hasil Penelitian, pp 84-88.

Swaminathan, S, Padmapriyadarsini, C, Venkatesan, P, Narendran, G, Kumar, RS, Iliayas, S, Menon, PA, Selvaraju, S, Pooranagangadevi, NP, Bhavani, PK, Ponnuraja, C, Dilip, M, \& Ramachandran, R. (2011). Efficacy and Safety of OnceDaily Nevirapine- or Efavirenz-Based Antiretroviral Therapy in HIV-Associated Tuberculosis: A Randomized Clinical Trial, Clinical Infectious Diseases, , 53(1), 716-724.

Wells-Parker, E., Williams, M., Dill, P., \& Kenne, D., (1998). Stages of change and selfefficacy for controlling drinking and driving: A psychometric analysis. Addictive Behaviors, 23(3), pp351-363.

Wieland, M. L., Nelson, J., Palmer, T., O'Hara, C., Weis, J. A., Nigon, J. A., \& Sia, I. G., (2013). Evaluation of a tuberculosis education video among immigrants and refugees at an adult education center: a community-based participatory approach. Journal of Health Communication, 18(3), pp343-353. 